$14: 914$

$<$ 原 著 $>$

劇症肝炎における糖代謝異常に関する臨床的・基礎的検討

$\begin{array}{lrrrrl}\text { 加納 } & \text { 隆 } & \text { 大谷 } & \text { 雅彦 } & \text { 川本 } & \text { 智章 } \\ \text { 井戸 } & \text { 健一 } & \text { 木村 } & \text { 健* }^{*} & \text { 河合 } & \text { 秀子 } \\ \text { 杉原 } & \text { 潤一 } & \text { 冨田 } & \text { 栄一 } & \text { 武藤 } & \text { 泰敏** }\end{array}$

要 旨：劇症肝炎 (FH) における糖代謝異常を臨床 2 病型, 予後別に検討した。 その結果，入 院時の低血糖は急性型 (FHA) 死亡例では高率 (40\%) に, 一方亚急性型 (FHS) 死亡例では $4.2 \%$ みに, 生存例では全く認められなかった。 また，低血糖の出現もFHA 死亡例では病初 期に, FHS 死亡例では中一末期に多く認められた。一方, 高血糖の頻度はFHA 生存例に比し 死亡例で顕著で, 死亡症例は末期に，生存例では病初期に多く見られた．また，FHではインス リン感受性は良好であり，FH モデルにおいてす著明な高インスリン血症が認められたが， IVGTT から求めた糖利用率およびITTによるインスリン感受性は良好であった，FH の栄盖 管理に際しては臨床病型ならびに肝予備能の程度を十分に念頭にいれて血糖を管理すべきと考 えられた。ささらに, FHにおける糖処理能, インスリン感受性は良好に保持されていることより FHに対する高エネルギー輸液療法の有効性, 妥当性が裏付けられた。

索引用語：劇症肝炎糖代謝異常 低血糖

はじめに

劇症肝炎 $(\mathrm{FH})$ の治㞠の基本は，肝罗死の進展を防 止して肝再生にとって最良な内部環境を整備すること であろう，その基本は，過不足のない栄炁素補給を確 立することである，FHでは，黄疸出現後す食欲不振， 悪心，嘔吐が持続し，さらに意識障害が加わるため経 口摄取エネルギー量は著しく減少する。特に，肝は糖 代謝の中心的葴器であることより FH では高率に糖 代謝異常が生し，血糖の桓常的維持に支障をきたす， 古くょりFHでは低血糖の頻度が高くLuckéによれ ば劇症肝炎の $9 \%$ に低血糖が認められたとしてい $ろ^{11}$. 従って, 劇症訮资をはじめとする急性肝疾患では ブドウ糖を中心とした経静脈的栄盖法が汎用されてき ている. しかし, 近年, FH には急性型と覀急性型の臨 床 2 病型が存在し，その成因，病態および予後に著し い差異のあることが明らかにされるに至り，各病型に 適合した治療法の選択が重要であると考えられ る2.3)．FHにおける糖代謝異常に関しても臨床 2 病型 別にみた検討が必要と思われるが未だ詳細な報告はな い.今回，著者らはFH 47例を対象として血糖の推移

- 自治医科大学消化器内科

**岐阜大学第 1 内科

〈受付日1992年 6 月29日 $>$
を 2 病型別, 予後別に検討し, $\mathrm{FH}$ 各病型に打ける糖代 謝異常の特徽と栄盖管理の問題点およびその対策を明 らかにした，さらに，急性肝不全モデルラットを用い， FHに抢ける糖代謝異常の発生機序ならびに外因性ブ ドゥ楉に対する糖処理能，インスリン感受性などに関 しても検討を加えた。

\section{对象およひ方法}

\section{1. 臨床的検討}

昭和53年から63年までに当科及び吱阜大学第 1 内科 で経験した劇症肝炎47例 $\{$ 急性型 (FHA) 23例，覀急 性型（FHS）24例 \}を対象として入院時の血糖值を臨 床病型，予後別に区分して検討した，患者背景および 入院時の一般肝機能検查成績を Table に示す. FHA 生存例は 8 例, FHA 死亡例は15例, FHS 生存例は 1 例，FHS 死亡例は23例である。なお，入院時すでに中 心静脈栄養にて管理されていたものはなかった。さら に, FHA 生存例 7 例, FHA 死亡例11例および FHS 死 亡例12例の計30例では入院後の血糖值の経時的变動を 詳細に検討した。 入院後の血糖のサンブリングは原則 として早朝空腹時としたが，血糖が不安定な症例では ブドウ糖またはインスリン投与量の変更時に逐次採血 した.これら30例の治療法としては, FHA 生存例 7 例 では血獎交換療法（PEx）が5例，グルカゴンーイン 
Table Clinical and biochemical data in survived and fatal patients with two clinical forms of fulminant hepatitis ; acute (FHA) and subacute (FHS) forms. Values are the mean \pm SD or means (minimummaximum values). Dr shows drugs as the etiology of FH. ${ }^{*} p<0.05,{ }^{* *} p<0.02,{ }^{* * *} p<0.01,{ }^{* * * *} p<$ 0.001 ; FHA survived vs. dead, ${ }^{p}<0.05, " p<0.02,{ }^{\cdots} p<0.01, \cdots p<0.001$; FHA dead vs. FHS dead, $\diamond$ $\mathrm{p}<0.05, \infty \mathrm{p}<0.02, \infty \mathrm{p}<0.01, \infty \infty \mathrm{p}<0.001 ;$ FHA survived vs. FHS dead.

\begin{tabular}{|c|c|c|c|c|}
\hline & \multicolumn{2}{|c|}{ Acute form } & \multicolumn{2}{|c|}{ Subacute form } \\
\hline & Survived & Dead & Survived & Dead \\
\hline No. of individual & 8 & 15 & 1 & 23 \\
\hline Males: Females & $4: 4$ & $7: 8$ & $1: 0$ & $12: 11$ \\
\hline Age(yrs) & $41 \pm 15$ & $45 \pm 18$ & 36 & $47 \pm 15$ \\
\hline A : B : NANB : Dr. & $0: 3: 3: 2$ & $0: 8: 7: 0$ & $0: 0: 1: 0$ & $0: 4: 13: 6$ \\
\hline T.P. $(\mathrm{g} / \mathrm{d} l)$ & $5.6 \pm 0.5$ & $5.7 \pm 0.9$ & 5.8 & $5.7 \pm 0.8$ \\
\hline Alb. $(\mathrm{g} / \mathrm{d} l)$ & $3.1 \pm 0.4$ & $3.3 \pm 0.5$ & 3.1 & $3.0 \pm 0.5$ \\
\hline T. Bil $(\mathrm{mg} / \mathrm{d} l)$ & $11.2(3.5-26.5)$ & $15.8(10.5-26.7)^{000}$ & 13.1 & $24.0(3.6-44.4)^{000}$ \\
\hline D. $\operatorname{Bil}(\mathrm{mg} / \mathrm{d} l)$ & $8.0(3.0-19.6)$ & $8.2(4.1-15.7)^{\cdots}$ & 9.6 & $15.3(3.0-28.4) \infty 00$ \\
\hline GOT $(\mathrm{U} / l)$ & $2,528(172-7,560)$ & $1,740(363-4,700)^{\circ}$ & 1,580 & $872(160-2,810)^{\infty}$ \\
\hline $\mathrm{GPT}(\mathrm{U} / l)$ & $3.029(221-7.440)$ & $1.928(453-2.833)^{\cdots \cdots}$ & 2,500 & $944(203-3,540)^{\infty}$ \\
\hline $\mathrm{Ch}-\mathrm{E}(\Delta \mathrm{pH})$ & $0.55 \pm 0.22^{\circ}$ & $0.35 \pm 0.14$ & 0.33 & $0.29 \pm 0.140000$ \\
\hline GGT $(\mathrm{U} / l)$ & $145(61-283) \cdots$ & $67(9-163)$ & 100 & $58(7-165) \infty 00$ \\
\hline T. chol $(\mathrm{mg} / \mathrm{d} l)$ & $90 \pm 15$ & $100 \pm 34$ & 83 & $74 \pm 39$ \\
\hline PT $\quad \%$ & $25 \pm 11 * \cdots$ & $8 \pm 10^{\cdots \cdots}$ & 15 & $19 \pm 12$ \\
\hline HPT (\%) & $14 \pm 6^{* *}$ & $8 \pm 5$ & 10 & $11 \pm 9$ \\
\hline $\operatorname{AFP}(\mathrm{ng} / \mathrm{m} l)$ & $1,437(129-6,000)^{\circ}$ & $119(10-990)$ & 8.200 & $157(10-595)^{\circ}$ \\
\hline
\end{tabular}

スリン療法（GI）が全例に，ステロイド療法（GS）が 5 例に, $\mathrm{PGE}_{1}$ 製剤が 1 例になされ，1日のブドウ糖投

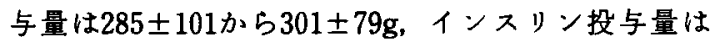
$14 \pm 5$ から15士5 単位であった。

一方, FHA 死亡例11例ではPEx が5例，GI は全例 に, GS 5 例に, hemoperfusion (HP) は 3 例, 交 換輸血（BE）が1例になされ，1日プドウ糖投与量は $204 \pm 91$ から251士109g，インスリン投与量は 1 例のみ

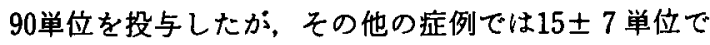
あった. FHS 死亡例12例ではPEx が 8 例, GI が全例 に, GS は 7 例，HP は 2 例，BEは 1 例になされ，1

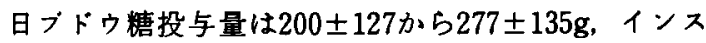
リン投与量は 1 例のみ80単位から始めたが他の例では $18 \pm 9$ からとし $30 \pm 20$ 単位まで使用した，なお，フミ ノ酸製剂としては全例に特殊組成フミ，酸製剂が500 $\mathrm{m} l$ 投与された，血糖はSMA 6/60にて測定した。 た，グルカコン負荷試験は既報に準じて施行し，負荷 後60分まで15分ごとに血糖および血墏 c-AMP を測定 しだ.

\section{2. 基礎的検討}

急性肝不全ラットは24時間絶食にした Wistar 系雄 性ラット $150 \mathrm{~g}$ にD-Galactosamine $800 \mathrm{mg} / \mathrm{kg}$ IP およ び Lipopolysaccharide (Salmonella enteritidis) $20 \mu \mathrm{g}$ IV にて作製し，頸静脈にカテーテルを留置し血糖，イ ソスリンおよびグルカゴン值を経時的に測定した。 た, FHにおける耐糖能およびインスリン感受性を検 討するためブドウ糖 $1 \mathrm{~g} / \mathrm{kg} の$ 経静脈的糖負荷試験 (IVGTT) および2U/kg 負荷のインスリン感受性試験 (ITT)を施行し糖消失率 $\mathrm{K}$ 值を Silverstone らの方法 に準じて解析しだ!。

\section{3. 統計学的処理}

各値は平均値士標準偏差(mean $\pm \mathrm{SD}$ )あるいは平均 値 (最小一最大値) で表記し, 有意差検定は paired-ttest, Wilcoxon signed rank test おょび $\chi^{2}$ 検定によ り行い, $\mathrm{p}<0.05$ を有意とした，また，血糖消失率 $\mathrm{K}$ 值 は最小二乗法により回㷌直線を作成して求めた。 


\section{成 績}

\section{1. 劇症肝炎臨床 2 病型, 予後別に見た入院時の血糖} 值

入院時の FHA 死亡例の血糖値は $70 \pm 30 \mathrm{mg} / \mathrm{d} l$ と FHA 生存例の $194 \pm 99 \mathrm{mg} / \mathrm{d} l$ K比し有意な低值 $(\mathrm{p}<$ $0.001)$ を示し, しかも血糖 $60 \mathrm{mg} / \mathrm{d} l$ 末満の低血糖の頻 度は後者では全く認められなかったのに対し，前者で は15例中 6 例 (40\%) と高率に見られた。一方，FHS 死亡例の入院時における血糖値は $146 \pm 85 \mathrm{mg} / \mathrm{d} l$ と正 常值を示し，低血桾の頻度も23例中 1 例 (4.3\%) のみ であった. FHS 生存例 1 例は $148 \mathrm{mg} / \mathrm{d} l$ を示した(Fig. 1).

\section{2. 劇症肝炎における入院時の昏睡度と血糖值}

入院時の昏睡度と血糖值との相関性を臨床病型, 予 後別に検討した(Fig. 2).FHA ではどの告睡度におい て字生存例が死亡例に比し高値を示し，さらに死亡例

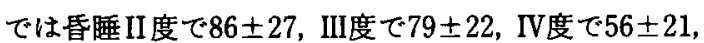
$\mathrm{V}$ 度では $31 \mathrm{mg} / \mathrm{d} l$ と昏睡度の進行に並行して血糖の 低下が認められた。一方, FHSでは 1 例を除いて入院 時の昏睡度がIII度以下であったが，各昏睡度間で血糖 值に差異は認められす大部分の症例で正常範囲内の値 を呈した。

\section{3. 劇症肝炎における入院時の低血糖の頻度と一般 肝機能検查成績}

FHA における入院時の低血糖の頻度と一般肝機能 検查成績との相関性を倹討した，FHAの予後推定に 有用と考えられている直接ビリルビン/総ビリルビン 比が0.55未满を示す症例では 12 例中 5 例 $(41.7 \%$ ）に 低血糖が認められたのに対し，0.55以上の症例では11 例中 1 例（ $9 \%)$ のみであった $(\mathrm{p}<0.10)$. また, プ ロ卜ロンビン時間（活性度）が10\%未満の症例では 14 例中 6 例 (42.9\%) に低血糖が見られたが，10\%以上 の症例 9 例では 1 例にも認められなかった（p< $0.05)$.

4. 劇症肝炎郖床 2 病型,予後別に見た血糖值の推移 FHA 生存例 7 例, FHA 死亡例11例および FHS 死 亡例12例に拈ける入院後の血糖値の経時的変動を比較 検討した(Fig. 3).FHA 生存例では全経過を通して低 血糖は全く見られず，高血糖も入院初期に散見された がその後は認められず全体として血糖の変動幅は小さ かった，FHA 死亡例では入院時あるいは入院初期に 高率に低血糖が認められた。一方，FHS 死亡例では FHA 死亡例と異なり病期間の中期から末期に低血糖 が認められた。ささらに，死亡例では生存例に比し高血 糖が頻発し，その程度も高度であった。

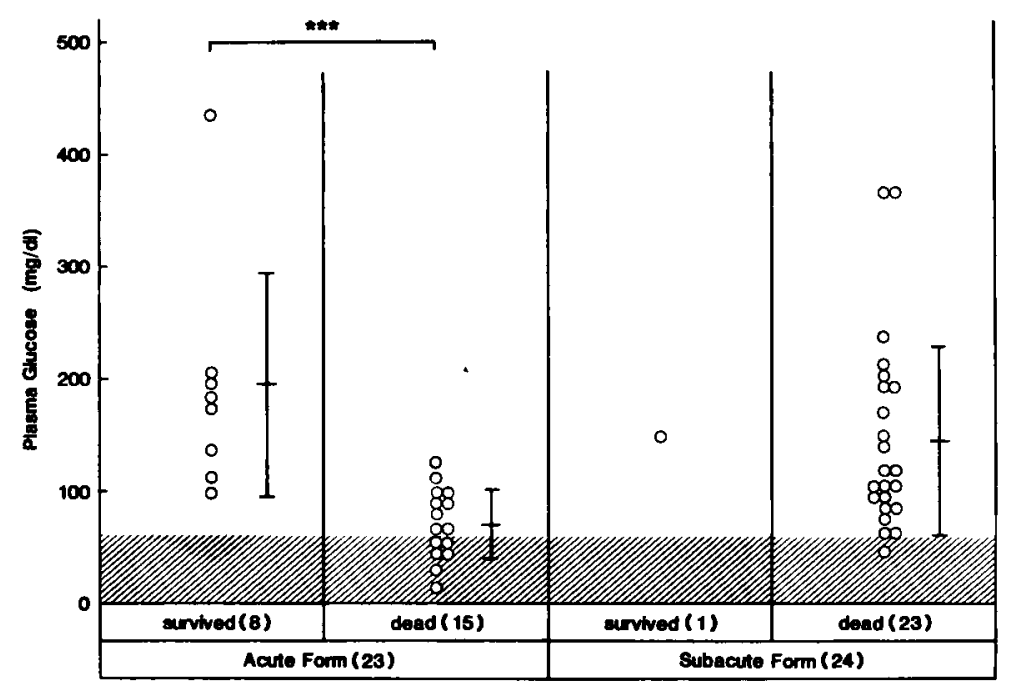

Fig. 1 Plasma glucose levels on admission in patients with two clinical forms of fulminant hepatitis; acute and subacute forms in comparison with survived and fatal cases. Shaded area shows the plasma glucose below $60 \mathrm{mg} / \mathrm{d} l$. Parentheses show the numbers of patients. * " $p<0.001$ 

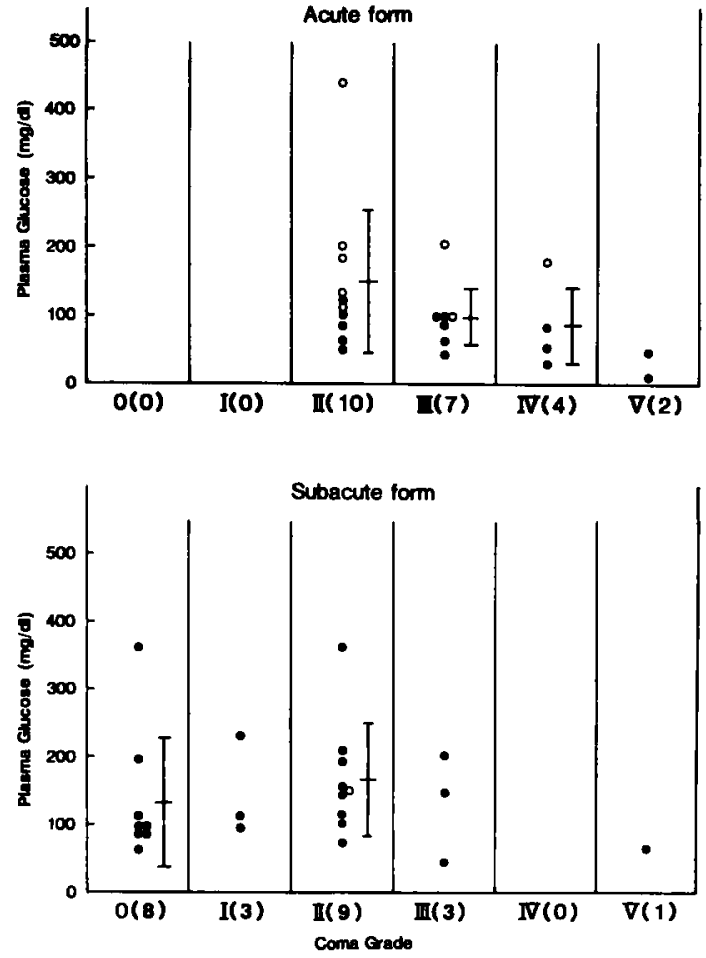

Fig. 2 Relationship between plasma glucose and coma grade on admission in patients with two clinical forms of fulminant hepatitis, acute and subacute forms. Parentheses show the numbers of patients. $\bigcirc$; survived, $\bullet$; deceased case.

\section{5. 劇症肝炎における低血糖の出現時間一臨床 2 病 型および予後別からの検討}

FH の経過中 (Fig. 3)に認められた最低血糖値の出 現時期を個々の症例における入院病日を 3 等分するこ とにより決定した病初期 (E)，中期 (M)，および後期 （L）の3期に区分して検討した（Fig. 4).FHA 生存 例では，どの時期においても $60 \mathrm{mg} / \mathrm{d} l$ 未満の低血糖は 認められなかったのに対し，FHA 死亡例では病初期 に 7 例中 5 例 $(71.4 \%)$ ，中期に 3 例中 2 例 $(66.7 \%)$ と病期の比較的早い時期に低血糖を示す例が多く，

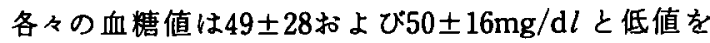
呈した。一方, FHS 死亡例では中期に 5 例中 3 例 $(60 \%)$ ，後期に 3 例中 2 例（66.7\%）と病期の比較的 遅い時期に低血糖例が多く認められ，各々の血糖値は $56 \pm 31 お よ ひ ゙ 47 \pm 63 \mathrm{mg} / \mathrm{d} l$ であった.なお, FHA 生存 例の病初期における血糖値 $106 \pm 5 \mathrm{mg} / \mathrm{d} l$ に比し FHA 死亡例の病初期の血糖值は有意な低下（p<0.05）を示

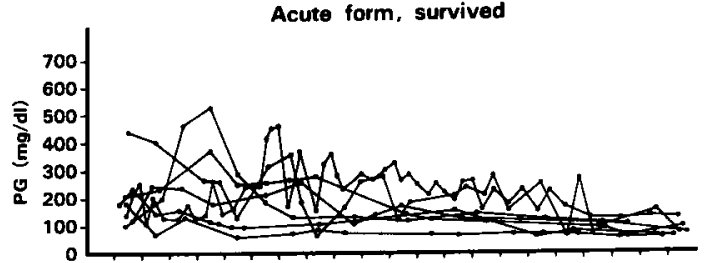

Acute form, died
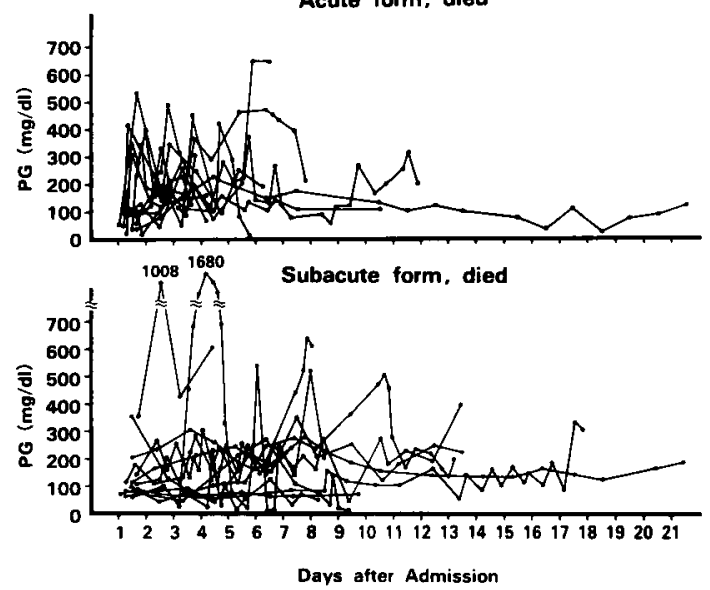

Fig. 3 Serial changes of plasma glucose levels in patients with two clinical forms of fulminant hepatitis, acute and subacute forms in comparison with survived and fatal outcome cases.

した。

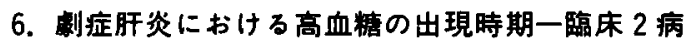
型およひ予後別からの検討

劇症肝资の経過中 (Fig. 3)の最高血糖値とその出現 時期を上記のごとく 3 期に分け臨床 2 病型, 予後別に 検討した（Fig. 5). 血糖 $300 \mathrm{mg} / \mathrm{d} l$ 以上の高血糖の頻 度 はFHA 生存例 $57.1 \%$ 対して FHA 死亡例 $72.7 \%$, FHS 死亡例 $75 \%$ と死亡例で高い傾向にあり， かつ高血糖の出現時期も生存例では病初期に，一方死 亡例では末期に多く認められた。

7. 劇症肝炎における血裾の最大日内变動一臨床 2 病型および予後別からの検討

FHにおける末梢組織でのインスリン感受性および 榶利用度を臨床的に類推するため血糖の最大日内变動

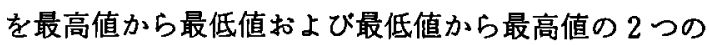
動きから検討した（Fig. 6). 高エネルギー輸液に伴う 血糖上昇はFHA では生存例の151

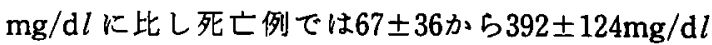
とより急峻であった。一方，インスリン等に伴ら血糖 低下度はFHA 生存, 死亡間で差異は見られずともに 


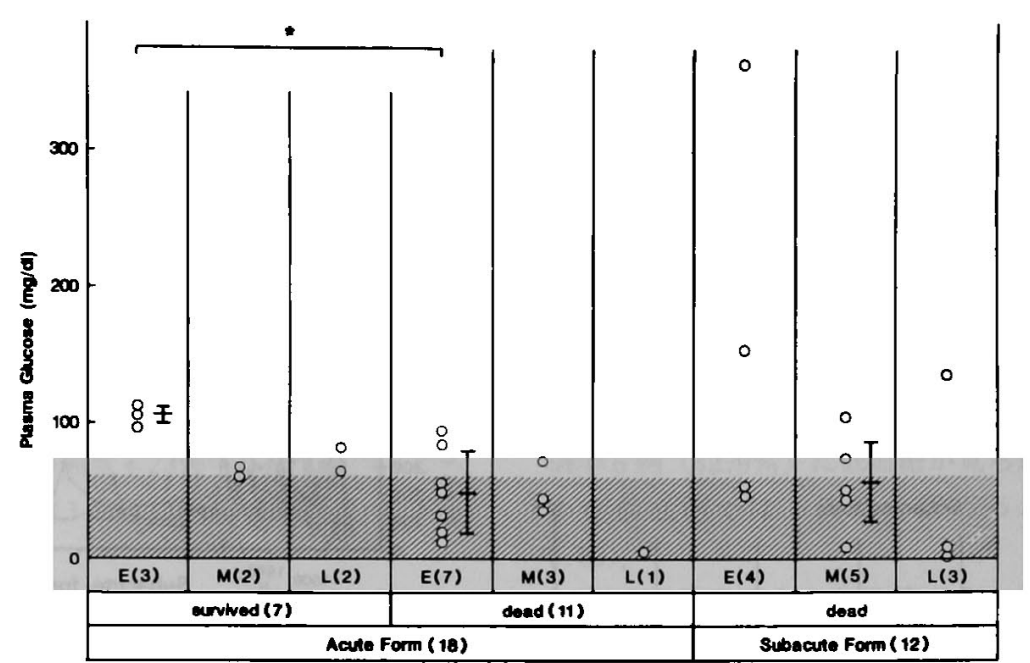

Fig. 4 Minimum levels of plasma glucose in clinical courses and period of onset of hypoglycemia in patients with two clinical forms of fulminant hepatitis, acute and subacute forms in comparison with survived and fatal outcome cases. Shaded area shows the plasma glucose below $60 \mathrm{mg} / \mathrm{d} l$. Parentheses show the numbers of patients. Period of hypoglycemia : E ; early, M ; middle, L ; late. *p< 0.05 .

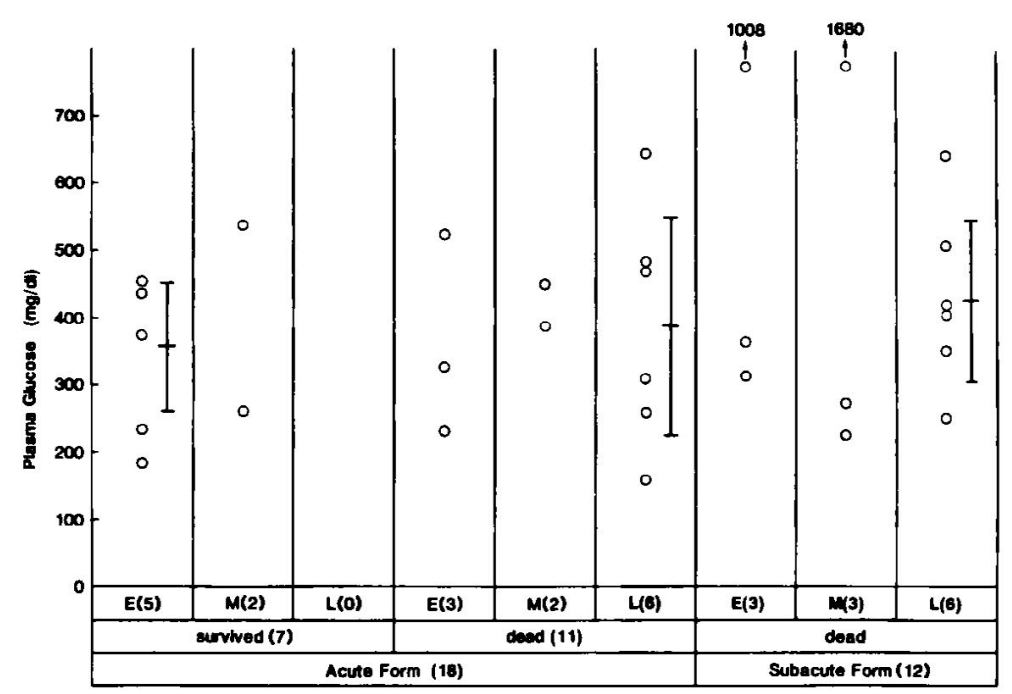

Fig. 5 Maximum levels of plasma glucose in clinical courses and period of onset of hyperglycemia in patients with two clinical forms of fulminant hepatitis, acute and subacute forms in comparison with survived and fatal cases. Parentheses show numbers of patients. Period of hyperglycemia : E; early, M ; middle, L ; late.

良好であった.FHS 死亡例では 3 例において輸液後, 血糖値の著しい上昇が見られ，血糖低下に関しても 3 例で低血糖域の値を示した。

\section{8. 䛻症肝资における榶新生系}

タルカゴン負荷後の血漿 c-AMP および血糖値の増 加量から見た FHにおける糖新生能を健常者および 


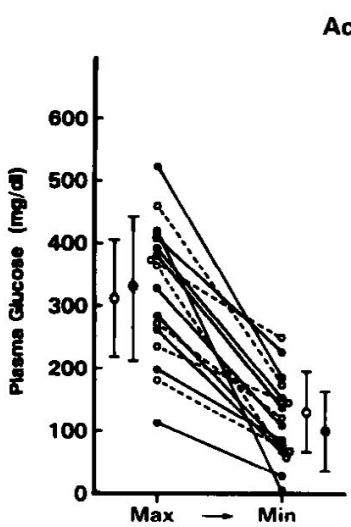

Acute form
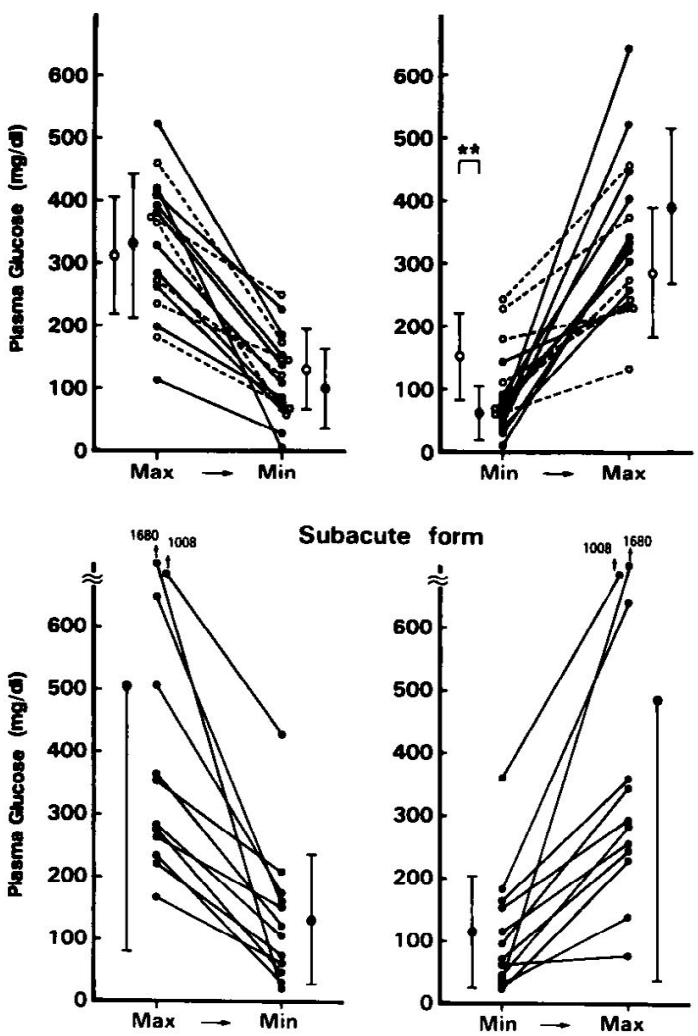

Subacute form

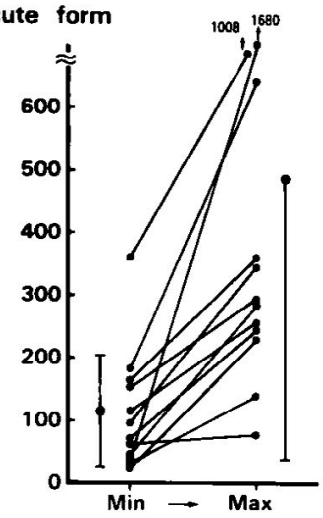

Fig. 6 Maximum daily changes (maximum to minimum or minimum to maximum) of plasma glucose in patients with two clinical forms of fuiminant hepatitis; acute and subacute forms in comparison with survived and fatal cases. 0 -. 0 ; survived, $\bullet-\bullet$; deceased case. ${ }^{* *} \mathrm{p}<0.02$.

肝硬変と比較検討した（Fig. 7)。グルカゴン負荷後 15 分の血漿 c.AMP 増加量は, FH では $55 \pm 56 \mathrm{pmoles/}$ $\mathrm{m} l$ と健常者の $928 \pm 211$, 肝硬変代償性 (LC-C)の $493 \pm$ 133 （ともに $\mathrm{p}<0.001)$ ，非代情性（LC-D）の221士 $71(\mathrm{p}<0.01)$ に比し有意な低值を示した。一方，負荷 後30分の血糖増加量は $\mathrm{FH}$ ではー $6 \pm 8 \mathrm{mg} / \mathrm{d} l$ と健常 者の $48 \pm 8$, LC-C の $18 \pm 7$ (ともに $\mathrm{p}<0.001$ ), LC-D

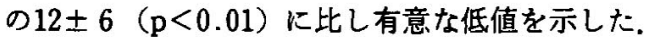

9. 急性肝不全ラットにおける血糖, 末梢血インスリ ン, グルゴン值の経時的変動

D-ガラクトサミンおよびLPSにより作製した急性 肝不全 (AHF) ラットにお汁る血糖扰よび末梢血イン スリン（IRI）お上びグルコン（IRG）值の経時的変 動を見た（Fig. 8). 臨床例におけると同様, AHF ラッ
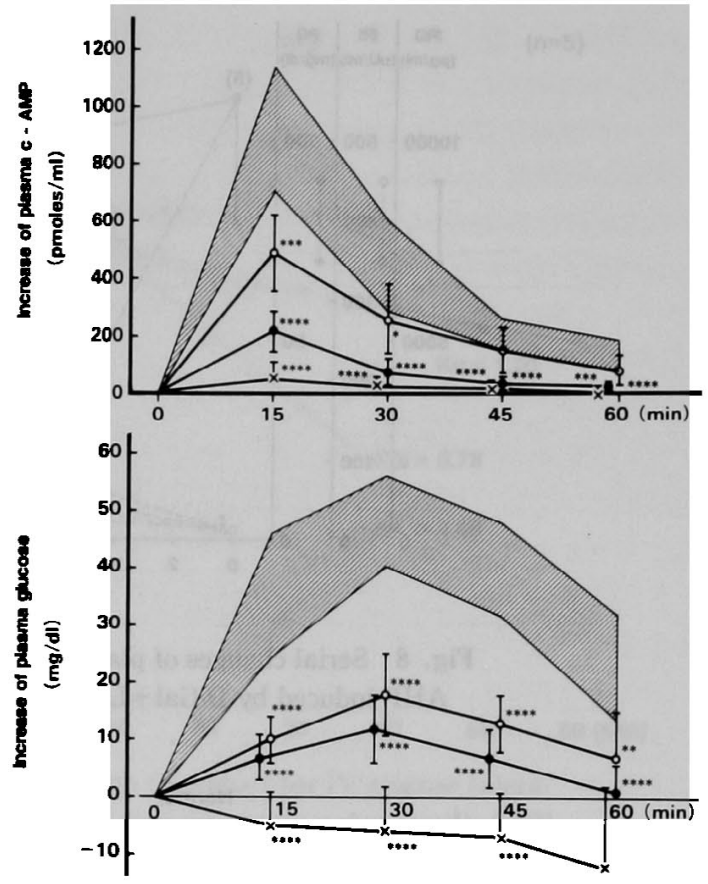

Fig. 7 Responses of plasma c-AMP and glucose to exogenous glucagon in patients with fulminant hepatitis (FH) and liver cirrhosis (LC). Shaded area shows mean. $\pm S D$ in normal subjects $(n=$ 7). O-O; compensated LC $(n=7),--\bullet$; decompensated LC $(n=8), \times-\times ; F H(n=5)$. "p $<0.05, * * p<0.02, * * * p<0.01,{ }^{* * * *} p<0.001$ vs. normal subjects.

トでは肝塤死の進行に並行して血糖値の低下が見ら れ，投与後18時間まで生存したるのでは $44 \pm 11 ， 23$ 時 間生存では $18 \pm 1 \mathrm{mg} / \mathrm{d} l$ までに漸減したが, 投与後 6 時間および12時間と早期に死亡したものでは各々 $26 \pm$ 17 お び $9 \pm 5 \mathrm{mg} / \mathrm{d} l$ と急激な血糖の低下が認められ た。一方，IRI 拈よびIRG は血糖の低下に相反して上 昇を示し投与23時間後には各々 $459 \pm 61 \mu \mathrm{U} / \mathrm{m} l$ お よ

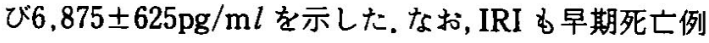
でその上䄯は顕著であった。

10. 急性肝不全ラットにおける耐糖能とインスリン 感受性

AHF ラットおよび健常ラットにおける耐糖能を1 $\mathrm{g} / \mathrm{kg}$ のIVGTTにより,さらにインスリン作用を IVGTT 2 分後に actorapid insulin 2 単位/ $\mathrm{kg}$ を投与 するITTにより検討した(Fig. 9)。 まず，AHF ラッ トにおけるIVGTTでは健常ラットに比し負荷後 10 分後までの血糖减衰は遅延していたか，その後の下降 


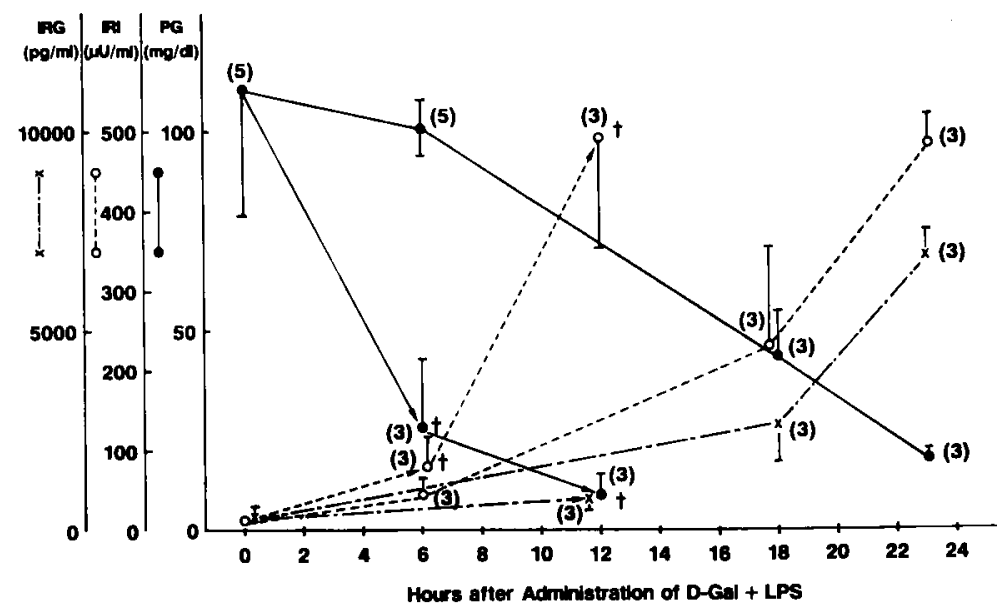

Fig. 8 Serial changes of plasma glucose, insulin and glucagon levels in rats with AHF induced by D-Gal+LPS. Parentheses show numbers of rats. $\dagger$; deceased.
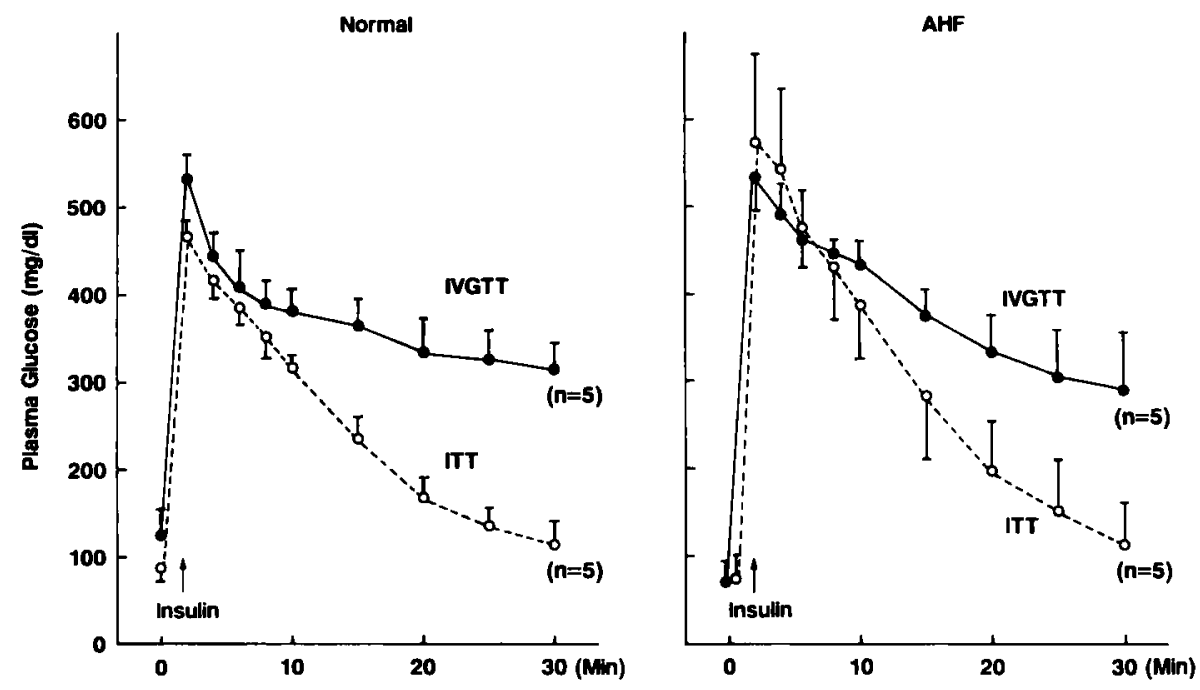

Fig. 9 Changes of plasma glucose on intravenous glucose tolerance test (IVGTT) and insulin tolerance test (ITT) in normal rats and rats with AHF induced by D-Gal+LPS.

には差異は認められなかった。さらに，ITTに関して むAHFおよび健常ラット間で血糖降下度に差異は見 られなかった．AHFラットおよび健常ラットにおけ るIVGTTおよびITTの血糖消失率 K 值を求めた (Fig. 10). IVGTTにおける K 值は two components よりなり volume componentは健常ラットの5.54に 対し AHF ラットでは3.01と低値を示したが, maintenance component における榶消失率 $\mathrm{K}_{\mathrm{G}}$ 值は $\mathrm{AHF}$ 群 は1.30, 健常群は1.14 と差異は見られなかった。一方。
ITT における血糖消失率 $\mathrm{K}_{\mathrm{G}}$ 値も AHF 群の5.78に比 し健常群では5.52を示し両群間で差異は認められな かった。従って, $\mathrm{K}_{\mathrm{GI}}$ と $\mathrm{K}_{\mathrm{G}}$ 值の盖で示される $\Delta \mathrm{K}$ 值は $\mathrm{AHF}$ 群の4.48に比し健常群では4.38 と同等の值を示 した.

$$
\text { 考案 }
$$

肝は糖，蛋白質・アミノ酸および脂質代謝の中心的 蔵器であることより, 劇应肝炎 (FH) ではこれらの代 謝に重大な異常が生じこの病態に適合した対応が要求 


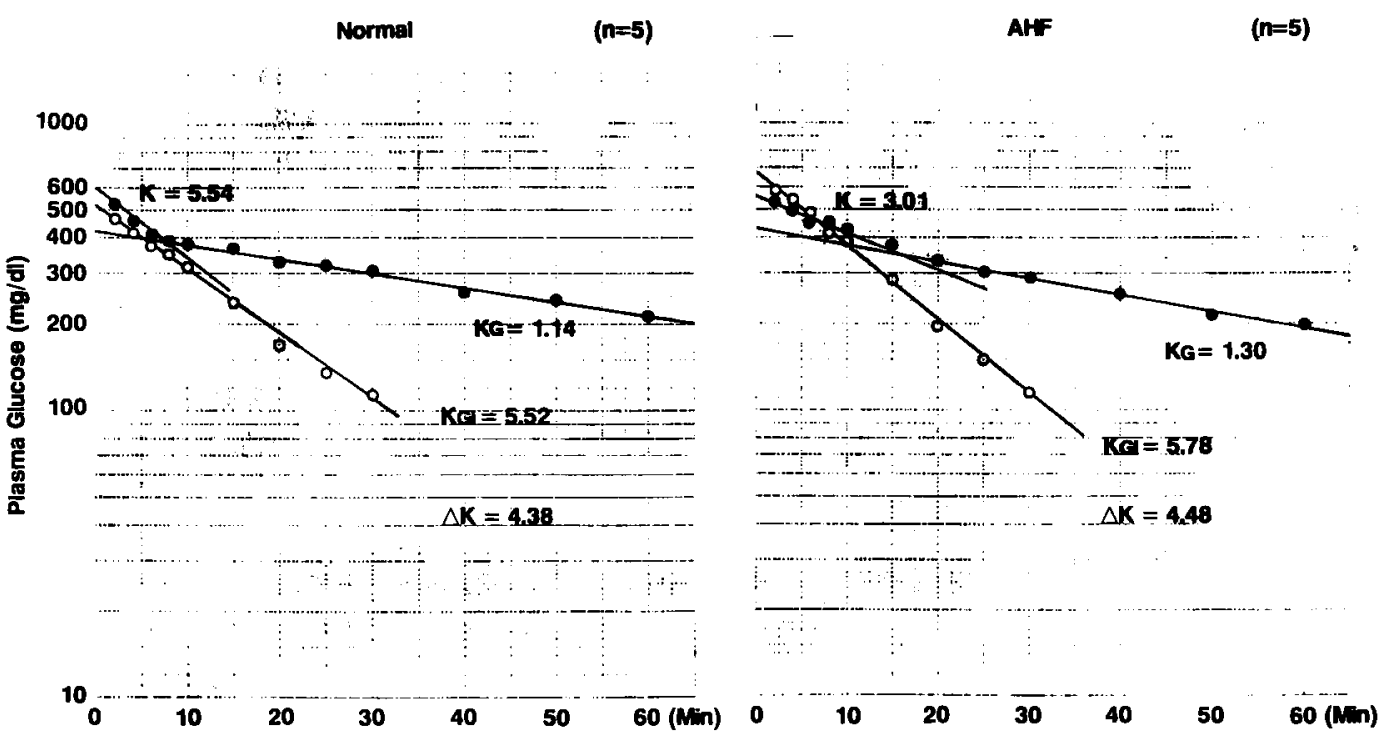

Fig. 10 Estimation of the plasma glucose disapperance rate ( $K$ value) for IV glucose tolerance $\left(\mathrm{K}_{\mathrm{G}}\right)$ and the $\mathrm{K}$ for IV glucose-insulin tolerance $\left(\mathrm{K}_{\mathrm{GI}}\right)$ in normal rats and rats with AHF induced by $\mathrm{D}-\mathrm{Gal}+\mathrm{LPS}$

される.近年, FH 急性型の予後は著明に改善されてき ているが3),これは早期診断体系の確立あるいは種々 の特殊治療法の開発に加え，上記代謝異常に対する式 速な栄養療法ならびに全身管理の確立に起因するとこ ろが大きいと考えられる6)。しかし，FHでは，黄疸出 現後も食欲不振，悪心，嘔吐が持続し，さらに意識障 害が加わるため経口摄取エネルギーは著しく減少す る. 特に, 肝は糖代謝の中心的葴器であることょり FH では高率に糖代謝異常が生じ，血糖の恒常的維持に支 障をきたす. Luckéによよれば予後不良な FH の $9 \%$ に 低血榶が認められ，その出現時期は何等かの神経症状 が見られる末期であると報告している1，しかし，FH には急性型 (FHA) と亜急性型 (FHS) の臨床 2 病型 が存在し，その成因，病態扰よび予後に著しい差異の

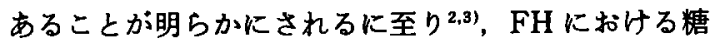
代謝異常の病態を論じる場合にも臨床 2 病型，予後別 に見た倹討が必要と考えられる，今回，著者らはFH 各病型，予後別に区分して詳細に検討した結果，入院 時における低血糖はFH の臨床病型，肝予備能，予後 を良好に反映して出現した。すなわち，FHA 死亡例で は高頻度 $(40 \%)$ に，一方 FHS 死亡例では $4.3 \%$ み に, 生存例では全く認められなかった。 FH 臨床 2 病型 別から見た意識障害発現時の低血糖の頻度に関して は，FHA では14\%，FHS では $5 \%$ といら冨田の報告
があるが7)，今回の臨床 2 病型および予後別に見た低 血糖の頻度はFHS では同等であったが, FHA 死亡例 では高く今回対象とした予後不良例では肝予備能の低 下が著しく，かつ入院までのブドウ糖投与量が不十分 であったと推測された。なお，FHAにおいては入院時 の昏睡度执よび予後推定に有用な生化学的パラメー ターと血糖值の間には相関性が認められたことより FHにおける低血糖の機序としては栄養素摂取の著 减，肝㕕汎壊死に伴う肝グリコーゲン蓄積の減少およ び糖新生系の破綻に起因すると考えられた。実際，今 回の著者らの検討です FHではグルカゴ負荷に対 する血墏 c-AMP の反応性は極めて悪く，血糖の増加 も全く見られずむしろ低下を示した。

今回，著者らはさらに FH 臨床 2 病型，予後別に見 た入院後の血糖値の推移に関しても検討を加え，FH に拈ける低血糖, 高血桾の出現時期が病型, 予後によっ て異なることを初めて明らかにした。 即ち, FHA 生存 例では全経過を通じて低血糖は全く見られず，全体と して血糖の変動幅は小さかった，FHA 死亡例では入 院初期に高率に低血榶が認められ，一方 FHS 死亡例 では病期間の中期から末期に低血糖が認められた。さ らに, 死亡例では生存例に比し高血糖が末期に頻発し， その程度も高度であった. 著者らは, FH の臨床病型, 予後別の肝予備能をクルカゴン負荷試験により検討 
し，FHA 死亡例では入院時すでに著しい肝予備能低 下が見られること，一方 FHA 生存例では死亡例に比 し高い予備能を有し，しかも病状の改善とともに急速 に改善を示すこと，さらに，FHS 死亡例では入院時の 肝予備能は比較的良好に保持されているか，その後悪 化し不虑の転㷌をとることなどを明らかにしてい $3^{8-10)}$. 今回の検討で見られた入院後の糖代謝異常む, その程度，出現時期からして肝予備能の低下に強く依 存して出現していることが同われた. 実際, AHF モデ ルラットに打いてもこの糖代謝異常は再現され，肝壊 死の進行に並行して血糖の低下が見られとくに早期に 死亡するものでは顕著であった。

もう 1 つ因子としてはブドウ糖扰よびインスリン 投与量の差異が考えられた。今回対象とした FH 臨床 2 病型，予後別に区分した各群における治療法の選択 には差異は認められなかったが，1日ブドウ糖投与量 は生存例が死亡例に比し多かった。一方，インスリン 投与量はFHA 生存㧍よび死亡例では同等であった が, FHS 死亡例では高血糖に対し20－50単位が投与さ れていた，古くより急性肝炎に関しては 5 ないし $10 \%$ ブドウ糖溶液の点滴がなされ，上野は糖質を与克るこ とにより肝壊死の予防に利点があるとしている゙11. 現 在, $\mathrm{FH}$ の栄養療法は完全経静脈栄養法を基本として ブドゥ糖を $10 \mathrm{~g} /$ 時間の速さで持続投与し，GI 療法 (10\%ブドウ糖にグルカゴン $1 \mathrm{mg}$, インスリン10単位を 加之 2 - 3 時間で投与)を 1 日 2 クール施行，GI 療法 後特殊フミノ酸輸液を各々 $250 \mathrm{ml}(10 \%$ ブドウ糖液に 調整）を投与することを勧めている（1日量としてブ ドウ糖 $340 \mathrm{~g}, フ ミ ノ$ 酸 $40 \mathrm{~g}$, 総 ネルギー1,520 $\mathrm{kcal}^{22)}$. 今回の対象症例のブドゥ榶投与量はいずれも 推奖量を下回り，とくに死亡例でその不足が顕著であ り, 改めて FHにおける中心静脈栄羡法の重要性が確 認された。

しかし，完全経静脈栄堆法によって十分なブドウ糖 量が投与されても有効に糖が利用されなければ意味が ない，今回，著者らはFHにおける糖処理能およびイ ンスリン感受性に関して臨床的，基礎的に検討した。 FHにおける高血糖の頻度はFHA 生存例に比しブド ウ糖の投与量が過少であった FHA およびFHS 死亡 例で高く，また高血糖の出現時期も生存例では病初期 に，一方死亡例では末期に多く認められた。ささらに, FHにおける血糖の最大日内変動を検討したが，高エ ネルギー輸液に伴う血糖上昇はFHA 生存例に比し FHA 死亡例でより急峻であった。Vilstrup は急性肝
不全の糖代謝率はコントロールの半分に低下している と報告しているが注，今回対象とした FHにおいても 死亡例でより強い耐糖能異常が認められた。FH にお。 ける高血糖は肝広汎壊死のため肝からの糖放出は著减 していると考えられるため経静脈的に投与されたブド ウ糖の全身臓器での糖取り込み率の低下および肝での ブドウ糖からグリューゲンへの貯蔵能の低下に起因す ると思われた ${ }^{14)}$. しかし，臨床上，血糖の最大日内変動 のらち最高値から最低値への变動幅はFHA 生存, 死 亡間で差異は見られずともに良好であった事より， FH では外因性インスリンに対する感受性は比較的良 好に保持されていると推測された，今回の基礎検討か らす FHA モデルラットでは著明な高インスリン血症 が認められたか，IVGTTから求めた糖利用率および ITTによるインスリン感受性は良好に保持されてい た。この実験モデルが実際の FH と同じ病㦔を呈する かには問題は残るが，血糖値とインスリン濃度および その相互作用が末梢組織での糖利用率を規定している ことから ${ }^{14}$ 血糖値が低く，かつ高インスリン血症の持 続期間が短く糖輸送担体の合成低下がないと考えられ る FH 病初期では榶利用，インスリン感受性は良好に 保持されていることか強く示唆され淿，FHに対する 高エネルギー輸液療法の有效性，妥当性が赛付けられ たと言えよう。しかし，FH 予後不良例の中にはインス リン抵抗性ならびに過鄱な高エネルギー輸液の持続に より著しい高血糖を示したり，あるいは逆に過度のイ ンスリンにより低血糖に陥るるのが在り，FHできめ 細かな糖およびインスリン量の調節，变更が寛容と考 えられた。

\section{結語}

劇症肝炎（FH）における糖代謝異常を臨床 2 病型, 重症度，予後別に検討し糖代謝から見た FH の治療法 の留意点を明らかにし以下の結論を得た。さらに，急 性肝不全モデルラットを用い，FHにおける糖代謝異 常の発生機序に関しても検討を加えた。

1. 入院時における低血糖は FH の臨床病型，肝予 備能，予後を良好に反映して出現し，急性型 (FHA) 死亡例では高頻度 $(40 \%)$ ，一方亜急性型（FHS） 死亡例では $4.2 \%$ みに, 生存例では全く認められな かった。

2. FH 経過中の低血糖の出現は，FHA 死亡例では 病初期に, FHS 死亡例では中一末期に多く認められ た.

3. FH における低血糖の機序としては低栄䅅拉よ 
び肝広汎壊死に伴ら肝グリコーゲン蓄積量の減少およ び糖新生系の破糘に起因すると考えられた。

4.FH 経過中に見られる高血糖は，FHA 生存例に 比し死亡例で顕著で，その出現時期も死亡症例は末期 に，一方生存例では病初期に多く認められた

5. 血糖の最大日内変動の5ち最高値から最低值へ の変動幅はFHA 生存, 死亡間で差異は見られずとも に良好であった事より，FHでは外因性インスリンに 対する感受性は比較的良好に保持されていると推測さ れた。

6. 急性肝不全モデルにおいても著明な高インスリ ン血症が認められたか，IVGTT から求めた糖利用率 およびITTによるインスリン感受性は良好に保持さ れていた。

以上の如く, FH の栄美管理に際しては臨床病型, 肝 重症度を十分に念頭にいれて血糖管理すべきと考えら れた。さらに, FHにおける糖処理能, インスリン感受 性は比較的良好に保持されていることより FHに対 する高かロリ一輸放療法の有効性, 妥当性が裏付けら れた。

尚, 本文の要旨は第31回日本消化器病学会大会 (1989年, 旭川)，第24回日本肝䁍学会東部会バネルディスカッション (1989年，長野)，第33回日本糖尿病学会総会(1990年，東京) および第77回日本消化器病学会 (1991年, 東京) に於いて発 表した。

\section{文 嗝}

1) Lucke $B$, Mallory $T$ : The fulminant form of epidemic hepatitis. Am J Path 22: 867-945, 1946

2）高橋善弥太：急性肝不全の臨床，とくに治療の面 から。纳会誌 $71: 1079-1096,1982$

3) Muto Y : Fulminant hepatitis - Is the survival improving? Gastroenterol Jpn 27: 142-144, 1992
4）加納 隆, 宮川秀子, 武藤泰敏, 他：肝予備能検査 法としての Glucagon 負荷による血中 cyclic AMP の反応性. 日消誌 $77: 195-205,1980$

5) Silverstone FA, Brandfonbrener M, Shock NW et al: Age differences in the intravenous glucose tolerance tests and the response to insulin. J Clin Invest 36 : 504-514, 1957

6）武藤泰敏,杉原潤一：劇症肝炎の臨床. 日本医事新 報 $3310: 3-10,1987$

7）冨田栄一：劇症肝炎臨床二病型に関する臨床病理 学的研究一自験例54症例を中心にして一，岐阜医 紀 $29: 1032-1070,1981$

8）加納 隆，武藤泰敏：急性肝不全に打けるクルカ コン負荷試験の臨床的意義。消化器病学とグルカ ゴン, 竹本忠良編, メディカルレビュー社, 東京。 1988, $\mathrm{p} 35-38$

9）武藤泰触, 富田栄一, 熊原 正, 他：肝再生の臨床. 肝胆膵 $17: 815-822,1988$

10）加納 隆：タルカゴソ負荷試験による重症肝炎の 肝予備能評価之その臨床的有用性。「肝渡病の臨床 一トピックスと展望」大菅拨明編，中外医学社，東 京, 1992, p247-251

11）上野幸久, 芳賀 稳：急性肝炎の予後と治療。肝炎 のすべて，高橋忠雄 編，南江堂，東京，1973，p154 $-166$

12）吉田 貴, 武藤泰敏：病態一肝炎一。肝胆膆 6 ： $831-840,1983$

13) Vilstrup $\mathrm{H}$, Iversen $\mathrm{J}$, Tygstrup $\mathrm{N}$ : Glucoregulation in acute liver failure. Eur J Clin Invest $16: 193-197,1986$

14）河盛隆造，森島豊彦，久保田昌詞，他：血糖コント ロールにおよぽす諸因子一肝蔵の糖代謝面から。 糖尿病学の進步 91 , 第25集, 日本糖尿病学会編, 診 断と治療社, 東京, 1991, p150-158

15）岡芳知：インスリンと糖膜輸送。糖尿病1986, 小 坂樹徳編，診断と治療社，東京，1986，p19-44 


\title{
Clinical and experimental studies on impaired glucose regulation in patients with two clinical forms of fulminant hepatitis
}

\author{
Takashi Kano, Masahiko OHTANI, Tomoaki Kawamoto, Kenichi Ido, Ken KIMURA*, \\ Hideko KaWaI, Junichi Sugrhara, Eiichi Tomita and Yasutoshi Muto**
}

To evaluate the frequency of hypo- or hyperglycemia, glucose regulatory mechanism and therapeutic problems in fulminant hepatitis (FH), we have examined the serial changes of plasma glucose levels in 47 patients with two clinical forms; acute (FHA) and subacute (FHS) forms of FH. The occurrence of severe hypoglycemia in fatal patients with FHA (40\%) was significantly higher than that of FHS (4.2\%). Furthermore, hypoglycemia of FHA was detected at an early stage, but that of FHS was observed at a terminal stage. On the other hand, none of the hypoglycemia found in survived cases of FH.

Difference in frequency and period of hypoglycemia between FHA and FHS suggests that hypoglycemia may occur due to rapid and massive hepatic necrosis. In fact, the plasma c-AMP and glucose responses to exogenous glucagon was significantly decreased in FH with fatal outcome. Experimentally, glucose disposal rates evaluated by IVGTT and ITT was normal in AHF rats. It is conceivable that therapeutic administration of glucose is fundamental and most important in medical management, especially at an early stage of $\mathrm{FH}$.

\footnotetext{
* Department of Gastroenterology, Jichi Medical School (Tochigi)

** First Department of Internal Medicine, Gifu University School of Medicine (Gifu)
} 